\section{Two polymorphisms at the DXS539 locus}

J.A.J.M.van den Hurk, J.C.F.M.Dreesen, H.van den Berg, C.A.van Bennekom, A.M.W.van den Ouweland and B.A.van Oost ${ }^{\star}$

Department of Human Genetics, University Hospital Nijmegen, PO Box 9101, 6500 HB Nijmegen, The Netherlands

Source/Description: pJH89 is a $2.3 \mathrm{kbp}$ SalI/PstI fragment isolated from a phage library derived from a reduced humanhamster somatic cell hybrid (908K1B17) and subcloned in pGEM3 (1).

Polymorphism: pJH89 detects two two-allele polymorphisms:

$\begin{array}{lll}\text { TaqI } & 2.6 \mathrm{kbp} & A 1 \\ & 2.2 \mathrm{kbp} & A 2 \\ \text { NcoI } & 5.5 \mathrm{kbp} & \text { B1 } \\ & 4.6 \mathrm{kbp} & \text { B2 }\end{array}$

With TaqI constant bands of $0.9 \mathrm{kbp}, 0.4 \mathrm{kbp}$, and $0.2 \mathrm{kbp}$ are seen and with $N c o I$ constant bands of $2.4 \mathrm{kbp}$ and $2.7 \mathrm{kbp}$ are seen.

Frequency: Allele Frequency Number of Chromosomes

$\begin{array}{lll}\text { A1 } & 0.16 & 160 \\ \text { A2 } & 0.84 & \\ \text { B1 } & 0.83 & 88 \\ \text { B2 } & 0.17 & \end{array}$

Not Polymorphic For: BamHI, BcII, BglI, BglII, EcoRI, EcoRV, HindIII, KpnI, MspI, PstI, PvuII, AvaII, SstI, and XbaI.

Chromosomal Localisation: Proximal but closely linked to FRAXA.

Mendelian Inheritance: $\mathrm{X}$-linked codominant segregation was observed in more than 20 Fragile- $X$ families.

Probe Availability: Write to B.A.van Oost.

Other Comments: The two polymorphisms are almost in equilibrium as the observed combined heterozygosity is $42 \%$. Genetic and physical mapping have demonstrated that DXS539 is located in between DXS369 and FRAXA (Dreesen et al., manuscript in preparation).

Reference: 1)Schonk,D. et al. (1989) Genomics 4, 383-396.

\section{EcoRI and Pvull RFLPs in the endonexin II/annexin V (ANX5) gene on chromosome four}

T.M.Ritty, M.Jaye ${ }^{1}$, R.Kaplan ${ }^{1}$ and J.C.Murray*

Department of Pediatrics, University of lowa, lowa City, IA 52252 and ${ }^{1}$ Rhone-Poulenc Rorer Central Research, 680 Allendale Road, King of Prussia, PA 19406, USA

Source/Description: $\mathrm{pRK} 6$ contains a $1.3 \mathrm{~kb} \mathrm{Ncol} / \mathrm{HindIII} \mathrm{cDNA}$ insert cloned from human placenta. Sequence of the insert extends from the NcoI site at the ATG to the HindIII site $323 \mathrm{bp}$ downstream of the translational stop codon. The vector is pKK233-2 (1).

Frequency:

\begin{tabular}{|c|c|c|c|}
\hline & Allele & $\begin{array}{l}\text { band size }(\mathrm{kb}) \\
18 \quad 13 \quad 127 \\
18 \quad 13 \quad 127\end{array}$ & frequency \\
\hline EcoRI & $\begin{array}{l}\text { A1 } \\
\text { A2 }\end{array}$ & $\begin{array}{l}++-+ \\
+-+t \\
1276.24 .83 .5\end{array}$ & $\begin{array}{l}.66 \text { (56 CEPH chromosomes) } \\
.34 \text { (heterozygosity }=.61 \text { ) }\end{array}$ \\
\hline PvuII & $\begin{array}{l}\text { B1 } \\
\text { B2 }\end{array}$ & $\begin{array}{l}++--+ \\
-++t+\end{array}$ & $\begin{array}{l}.44 \text { (134 CEPH chromosomes) } \\
.56 \text { (heterozygosity }=.49 \text { ) }\end{array}$ \\
\hline
\end{tabular}

Not Polymorphic For: AccI, AvaI, BamHI, BanI, BanII, Eco109, EcoRV, HincII, HindIII, KpnI, MspI, RsaI, SspI, StyI, XbaI, XhoI.

Chromosomal Localisation: 4q28-q32 (2).

Mendelian Inheritance: Co-dominant segregation was seen in 35 CEPH families.

Probe Availability: Contact M.Jaye.

Other Comments: Strong linkage disequilibrium was observed between the two RFLPs.

References: 1) J. Biol. Chem. 263, 8037-8042 (1988). 2) Cytogenet. Cell Genet. 52, 167 (1989). 